\title{
Association of Elevated Body Mass Index and Hypertension with Mortality: the CroHort Study
}

\author{
Sandra Mihel ${ }^{1}$ and Sanja Musić Milanovićc ${ }^{1,2}$ \\ ${ }^{1}$ Croatian National Institute of Public Health, Zagreb, Croatia \\ ${ }^{2}$ University of Zagreb, School of Medicine, Andrija Štampar School of Public Health, Department of Medical Statistics, \\ Epidemiology and Medical Informatics, Zagreb, Croatia
}

\begin{abstract}
A B S T R A C T
Aim of this study was to investigate association of elevated body mass index and hypertension with general mortality in the cohort from Croatian Adult Health Cohort Study (CroHort). Risk of death according to body mass index (BMI) and blood pressure category, in period 2003/08, was calculated for 7,490 respondents, out of which 6,682 were alive and 808 were dead in 2008. Among men aged 65 and more, elevated BMI was associated with lower risk of death, in accordance with obesity paradox recorded in some previous studies which showed that older men with higher BMI have lower risk of death. Among women aged 50-64 years, being hypertensive was associated with increased risk of death compared to normotensive respondents. Despite obesity paradox which should be further explored, activities on primary and secondary prevention of excess weight and hypertension should be encouraged as means to prevent premature mortality in Croatian population.
\end{abstract}

Key words: body mass index, overweight, obesity, hypertension, mortality, CroHort study

\section{Introduction}

Cardiovascular diseases are the leading cause of death in developed countries and are a rapidly growing cause of death in low- and middle-income countries. According to the Global Burden of Disease Study in 2002, the leading cause of burden of disease in Europe are cardiovascular diseases with a $23 \%$ share in all DALYs. Croatia has, according to the same source, cardiovascular diseases at the top of the list, with a proportion of $27 \%$ of all DALYs.

Over half of burden of disease are caused by seven leading risk factors. The leading risk factor globally is high blood pressure with a share of $12.8 \%$ and overweight is ranked $5^{\text {th }}$ with a share of $7.8 \%$ in the DALY burden. Among Croatians, elevated blood pressure is ranked second (after smoking) with a share of $13.8 \%{ }^{1}$.

In Croatia, ca. 50,000 people die annually. Mortality rate is relatively stable at around $11 \%$. More than $50 \%$ of all death causes are related to circulation diseases, due to which 26,235 people died $(591.2 / 100,000)$. The leading diagnostic entities are ischemic heart disease and cerebrovascular diseases (shares of $39 \%$ and $31 \%$ in circulatory disease group $)^{2}$. Ischemic heart disease caused death of 10,542 people (standardized rates: 157.75 / 100,000) which ranked Croatia in European countries with medium high mortality rates ${ }^{3}$.

High blood pressure and obesity are recognized as important risk factors for mortality all around the world ${ }^{4,5}$. Each year more then 7 million people die as a result of raised blood pressure and 2.6 million people as a result of being overweight or obese ${ }^{6-8}$.

The studies based on the Croatian Health Survey 2003 data noted prevalence of arterial hypertension (therapy administration or systolic pressure $=140$, or diastolic pressure $=90$ ) of $45.6 \%$ for man and $43 \%$ for women ${ }^{9}$.

In Croatia, the prevalence of overweight and obesity has been estimated at almost $60 \%$ of the adult population ${ }^{10}$, and any association between overweight and mortality might have important clinical and public health implications. Overweight and obese people have an increased risk of developing many serious conditions e.g. cardiovascular disease ${ }^{11,12}$, diabetes mellitus ${ }^{13}$, certain cancers ${ }^{14}$ like endometrial ${ }^{15}$, ovarian ${ }^{16}$, breast $^{16,17}$, cervical $^{16}$, prostate ${ }^{16,18}$, colorectal ${ }^{16,18}$, sleep apnea ${ }^{19}$. 
Aim of this study was to assess the association of elevated body mass index and hypertension with general mortality in the Croatian adult population cohort from Croatian Adult Health Cohort Study (CroHort).

\section{Sample and Methods}

\section{Sample}

Respondents who participated in Croatian Adult Health Survey 2003 (9,070 respondents) were contacted in 2008 in order to participate in the follow-up Croatian Adult Health Cohort Study (CroHort). They were 18 years or older at the time of the first survey. The contact was established with 6,682 persons ( $73.7 \%$ of the original sample), out of which 3,229 agreed to participate in follow-up survey (35.6\%), while 3,453 persons refused (38.1\%). For 808 persons ( $8.9 \%$ of the original sample) information was obtained that they had died. Contact with remaining 1,580 persons $(17.4 \%)$ was not established, meaning that there was no information available whether they were alive or not in 2008. Further details on this sample were described elsewhere ${ }^{20}$.

Only persons for which information whether they were alive in 2008 was available, were included in the analysis encompassing total of 7,490 respondents (82.6\% of the original sample), out of which 6,682 were alive in 2008 and 808 were dead.

\section{Variables}

Public health nurses measured blood pressure in respondents' homes, while weight and height used to calculate body mass index (BMI) were self-reported by respondents and recorded on a questionnaire by public health nurses. Blood pressure was measured twice during single visit using a mercury sphygmomanometer, with respondents seated for 20 minutes between the measurements.

Respondents whose BMI was lower than $25 \mathrm{~kg} / \mathrm{m}^{2}$ were classified as normal weight, those whose BMI was $25 \mathrm{~kg} / \mathrm{m}^{2}$ or higher, but lower than $30 \mathrm{~kg} / \mathrm{m}^{2}$ were classified as overweight, while those whose BMI was $30 \mathrm{~kg} / \mathrm{m}^{2}$ or higher were classified as obese.

Respondents who stated that they use anti-hypertensive drugs or whose average blood pressure calculated from two measurements was equal or higher than 140 $\mathrm{mmHg}$ for systolic or equal or higher than $90 \mathrm{mmHg}$ for diastolic blood pressure, were categorized as hypertensive.

Age of respondents used in analysis was from year 2003 and data about risk factors (BMI, hypertension) were also from 2003 survey.

\section{Statistical analysis}

Percentage of respondents who died in period 20032008 was calculated separately for men and women in three main age groups (18-34 years, 35-64 years, 65 years and older) and in two additional age subgroups (35-49 years, 50-64 years) for each BMI category: normal weight, overweight and obese as well as for both blood pressure states: normotensive and hypertensive.
The multiple logistic regression analysis (adjusted for age) was used to calculate OR for death in period 20032008 depending on BMI (enrolled as continuous variable) and presence of hypertension (enrolled as binary variable: normotensive/hypertensive), separately for men and women in each age group: $18-34$ years, $35-49$ years, 50-64 years, 65 years and older.

All confidence intervals (CI) were calculated with $95 \%$ probability levels.

Statistical analysis was performed using SPSS (version 14.01; License: Croatian National Institute of Public Health).

\section{Results}

Both among men and women no significant differences in percentage of respondents who died were recorded among normal weight, overweight and obese respondents in the age groups: $18-34$ years and $35-64$ years as well as in the age subgroups: $35-49$ years and 50-64 years, with exception of overweight men who had significantly lower percentage of respondents who died compared to those with normal weight in the age group 35-64 years and with exception of obese women who had significantly lower percentage of respondents who died compared to overweight women in the age subgroup 35-49 years.

Among men aged 65 years and older, significantly lower percentage of obese men died compared to normal weight men, while no significant differences were recorded among women in that age group (Table 1).

Among men, no significant difference between normotensive and hypertensive respondents in percentage of those who died was recorded in any age group, while among women aged 35-64 years percentage of hypertensive respondents who died was significantly higher compared to normotensive (Table 2).

For men, multiple logistic regression analysis showed that being hypertensive was associated with increased OR for death, while higher BMI was associated with lower OR for death among respondents aged 65 years and older. In younger age groups, neither BMI nor hypertension were associated with significant difference in OR for death.

For women, logistic regression analysis showed that being hypertensive was associated with increased OR for death among respondents aged 50-64 years, while neither BMI nor hypertension were associated with significant difference in OR for death among other age groups (Table 3).

\section{Discussion}

The results showed that being hypertensive was associated with increased OR for death in man aged 65 years and older and women aged 50-64 years. A correlation between mortality and high blood pressure has been widely shown. Several studies have showed that the mortality rate was higher among hypertensive adults than non hy- 
TABLE 1

NUMBER AND PERCENTAGE OF RESPONDENTS WHO DIED 2003-2008 ACCORDING TO THEIR WEIGHT IN 2003

\begin{tabular}{|c|c|c|c|c|c|c|}
\hline \multirow[b]{2}{*}{ Characteristic } & \multicolumn{2}{|l|}{ Men } & \multicolumn{3}{|c|}{ Women } & \multirow[b]{2}{*}{$95 \% \mathrm{CI}$} \\
\hline & Number & $\%$ & $95 \% \mathrm{CI}$ & Number & $\%$ & \\
\hline \multicolumn{7}{|l|}{ Age 18-34 } \\
\hline normal weight $(\mathrm{BMI}<25)$ & 8 & 4.3 & $1.4-7.2$ & 13 & 2.0 & $0.9-3.1$ \\
\hline overweight $(25 \leq \mathrm{BMI}<30)$ & 5 & 5.3 & $0.8-9.8$ & 4 & 3.1 & $0.1-6.2$ \\
\hline obese $(\mathrm{BMI} \geq 30)$ & 0 & 0.0 & & 2 & 4.2 & $0.0-9.8$ \\
\hline \multicolumn{7}{|l|}{ Age $35-64$ total } \\
\hline normal weight $(\mathrm{BMI}<25)$ & 35 & 10.5 & $7.2-13.8$ & 53 & 5.5 & $4.0-6.9$ \\
\hline overweight $(25 \leq \mathrm{BMI}<30)$ & 33 & 5.4 & $3.6-7.1$ & 60 & 6.3 & $4.8-7.8$ \\
\hline obese $(\mathrm{BMI} \geq 30)$ & 22 & 6.4 & $3.8-9.0$ & 31 & 5.0 & $3.3-6.7$ \\
\hline \multicolumn{7}{|l|}{ Age $35-49$} \\
\hline normal weight $(\mathrm{BMI}<25)$ & 13 & 7.8 & $3.7-11.9$ & 18 & 3.1 & $1.7-4.5$ \\
\hline overweight $(25 \leq \mathrm{BMI}<30)$ & 13 & 4.8 & $2.3-7.3$ & 22 & 5.3 & $3.1-7.5$ \\
\hline obese $(\mathrm{BMI} \geq 30)$ & 8 & 5.7 & $1.9-9.6$ & 3 & 1.4 & $0.0-3.0$ \\
\hline \multicolumn{7}{|l|}{ Age $50-64$} \\
\hline normal weight $(\mathrm{BMI}<25)$ & 22 & 13.1 & $8.0-18.2$ & 35 & 9.0 & $6.1-11.8$ \\
\hline overweight $(25 \leq \mathrm{BMI}<30)$ & 20 & 5.8 & $3.3-8.3$ & 38 & 7.1 & $4.9-9.2$ \\
\hline obese $(\mathrm{BMI} \geq 30)$ & 14 & 6.9 & $3.4-10.4$ & 28 & 6.8 & $4.4-9.3$ \\
\hline \multicolumn{7}{|l|}{ Age 65 and older } \\
\hline normal weight $(\mathrm{BMI}<25)$ & 79 & 31.2 & $25.5-36.9$ & 123 & 24.6 & $20.9-28.4$ \\
\hline overweight $(25 \leq \mathrm{BMI}<30)$ & 91 & 23.6 & $19.3-27.8$ & 129 & 18.5 & $15.6-21.4$ \\
\hline obese $(\mathrm{BMI} \geq 30)$ & 25 & 15.4 & $9.9-21.0$ & 93 & 18.4 & $15.0-21.8$ \\
\hline
\end{tabular}

TABLE 2

NUMBER AND PERCENTAGE OF RESPONDENTS WHO DIED 2003-2008 ACCORDING TO THEIR BLOOD PRESSURE IN 2003

\begin{tabular}{|c|c|c|c|c|c|c|}
\hline Characteristic & $\begin{array}{c}\text { Men } \\
\text { Number }\end{array}$ & $\%$ & $95 \% \mathrm{CI}$ & $\begin{array}{l}\text { Women } \\
\text { Number }\end{array}$ & $\%$ & $95 \% \mathrm{CI}$ \\
\hline \multicolumn{7}{|l|}{ Age 18-34 } \\
\hline normotensive & 9 & 3.6 & $1.3-5.9$ & 19 & 2.5 & $1.4-3.7$ \\
\hline hypertensive & 4 & 6.3 & $0.3-12.4$ & 0 & 0.0 & \\
\hline \multicolumn{7}{|l|}{ Age $35-64$ total } \\
\hline normotensive & 45 & 7.4 & $5.3-9.5$ & 60 & 4.3 & $3.3-5.4$ \\
\hline hypertensive & 45 & 6.5 & $4.7-8.4$ & 85 & 7.3 & $5.8-8.8$ \\
\hline \multicolumn{7}{|l|}{ Age 35-49 } \\
\hline normotensive & 23 & 6.9 & $4.2-9.6$ & 32 & 3.7 & $2.4-4.9$ \\
\hline hypertensive & 11 & 4.5 & $1.9-7.1$ & 12 & 3.5 & $1.6-5.5$ \\
\hline \multicolumn{7}{|l|}{ Age 50-64 } \\
\hline normotensive & 22 & 8.1 & $4.8-11.3$ & 28 & 5.4 & $3.5-7.4$ \\
\hline hypertensive & 34 & 7.6 & $5.2-10.1$ & 73 & 8.8 & $6.9-10.8$ \\
\hline \multicolumn{7}{|c|}{ Age 65 and older } \\
\hline normotensive & 38 & 19.0 & $13.6-24.4$ & 60 & 17.9 & $13.8-22.0$ \\
\hline hypertensive & 157 & 26.0 & $22.5-29.5$ & 286 & 20.9 & $18.8-23.1$ \\
\hline
\end{tabular}

pertensive adults ${ }^{21-23}$. The public health significance of hypertension results from the finding that it represents an independent risk factor for cardiovascular diseases. Progression of the hypertension is associated with vascular abnormalities that damage the heart, kidneys, brain and other organs, and leads to premature morbidity and death $^{24-28}$.

Compared to normotensive individuals, people with an elevated blood pressure have an increased tendency to have other risk factors for CVD (i.e. diabetes, dyslipidemia) ${ }^{29}$. 
TABLE 3

ASSOCIATION OF BMI AND HYPERTENSION WITH RISK OF DEATH IN PERIOD 2003-2008

\begin{tabular}{lcccc}
\hline & Men & \multicolumn{3}{c}{ Women } \\
Characteristic & OR* & $95 \%$ CI & OR* & $95 \%$ CI \\
\hline Age 18-34 & & & & \\
BMI & 0.93 & $0.79-1.10$ & 1.09 & $0.98-1.22$ \\
hypertension & 2.08 & $0.59-7.32$ & 0.00 & \\
\hline Age 35-49 & & & & \\
BMI & 0.97 & $0.90-1.06$ & 1.02 & $0.96-1.10$ \\
hypertension & 0.67 & $0.31-1.45$ & 0.87 & $0.42-1.79$ \\
\hline Age 50-64 & & & & \\
BMI & 0.93 & $0.87-1.00$ & 0.97 & $0.93-1.02$ \\
hypertension & 1.10 & $0.62-1.97$ & 1.65 & $1.03-2.65$ \\
\hline $\begin{array}{l}\text { Age 65 and older } \\
\text { BMI }\end{array}$ & 0.93 & $0.89-0.98$ & 0.99 & $0.96-1.01$ \\
hypertension & 1.53 & $1.01-2.30$ & 1.25 & $0.91-1.72$ \\
\hline
\end{tabular}

* adjusted for age

Systolic and diastolic blood pressure tends to rise with age and prevalence of hypertension increases after the age of 50 years. Some population studies have showed positive relationship between blood pressure and mortality at the age of 60-69 years, less in age group 75 years and older, but negative relationship in older than 85 years. This negative relationship in very elderly is probably caused by terminal phase of cardiac, respiratory and neoplastic disease and consequent low blood pressure ${ }^{30}$.

Analysis showed that in the age group 35-64 years significantly lower percentage of respondents died among overweight men compared to those with normal weight and in the age subgroup 35-49 years significantly lower percentage of respondents died among obese women compared to overweight women. Among men aged 65 years and older, higher BMI was associated with lower OR for death.

In several studies overweight and obesity are associated with increased all-cause mortality and showed an optimal BMI of 22.5 to 25.0 in analyses of all study participants $^{31-33}$.

Obesity has been clearly identified as a risk for premature death ${ }^{34-36}$, but the most studies recorded variability in the association of overweight and mortality. Flegal et al., Heather M.Orpana et al. and other authors found that underweight and obesity (particularly higher levels of obesity) were clear risk factors for mortality, but overweight was associated with a significantly decreased risk of death ${ }^{37-39}$.

Association between elevated body weight and excess deaths is not necessarily causal. Many factors influence mortality risk in addition to higher BMI. The reason for variability among studies assessing the association of BMI and mortality was that they had a different length of follow-up and inadequate control for confounder that might mask association of BMI with mortality ${ }^{40}$. This study has a short follow-up and it is possible that the pattern of results could change during a longer period of follow-up. The relation between BMI and all causes death differed according to smoking status, pre-existing chronic diseases and weight loss due to disease which may or may not be recognizable clinically ${ }^{38,41-44}$.

Due to the concern that pre-existing disease could influence the association between BMI and mortality, our analyses were also adjusted for hypertension, but not for other chronic diseases.

Smoking is an important confounder because people who smoke generally have a lower body mass index than non-smokers ${ }^{41,45}$.

People who smoke have a higher risk of death due to cardiovascular diseases (heart attack and stroke, peripheral vascular disease), chronic obstructive pulmonary diseases or cancer and low weight or weight loss may be in relationships with ill health. When assessing the relationship between body weight and mortality, it is important to taking smoking status and pre-existing disease into account ${ }^{46,47}$.

In the general population, obesity is associated with increased risk of adverse outcomes. Studies of patients with chronic disease suggest that overweight and obese patients may paradoxically have lower risk of death compared with those with normal weight. Pre-existing illness could lead to lower BMI and earlier mortality $43,47,48$.

In most reviewed studies, optimal BMI was associated with the lowest mortality increase with age and higher weight is not often associated with poor health ${ }^{49-53}$.

The results of this research support the obesity paradox presence in the elderly. They showed that being obese is a protective factor for death in men aged 65 years and older. Elderly with low BMI or weight loss may have chronic disease, co-morbidity and unrecognized illness which can be associated with higher mortality rates $^{54}$. In most populations, the body-mass index is correlated with more direct measures of body fat, but in elderly it may be a less useful indicator of adiposity. BMI may be relatively low among older people who have little muscle mass compared to adipose tissue and who tend to have a shift of fat from peripheral to central sites without increase in body-mass index ${ }^{55}$.

Many factors influence body weight and additional research to confirm association between BMI and mortality in different age groups would be of interest.

Excess body weight and hypertension are strong determinants as well as modifiable risk factors for all-cause mortality, and as such carry the potential for primary prevention. Despite variability in association of overweight and mortality among different age groups, a review of the literature provides much support for public health messages that advocate the benefit of change to healthier lifestyle regardless of age, in order to prevent excess body weight and hypertension as well as associated premature mortality. 


\section{Acknowledgements}

This article was prepared as a part of scientific project »Regionalism of cardiovascular behavioural risk factors -

\section{R E F E R E N C E S}

1. WHO, The European health report 2005: Public health action for healthier children and populations (WHO, Geneva, 2005). - 2. CROATINA NATIONAL INSTITUTE OF PUBLIC HEALTH, Croatian Health Service Yearbook 2009 (Croatina National Institute of Public Health, Zagreb, 2010). - 3. EUROPEAN HEALTH FOR ALL DATABASE, accessed on 25th May 2011. Available from: URL: http://data.euro.who.int/hfadb/. 4. EZZATI M, LOPEX AD, RODGERS A, VANDER HOORN S, MURRAY CJL, Lancet, 360 (2002) 1347. — 5. BANEGAS JR, LÓPEZ-GARCÍA E, GUTIÉRREZ-FISAC JL, GUALLAR-CASTILLÓN P, RODRÍGUEZ-ARTALEJO F, Eur J Clin Nutr, 57 (2003) 201. — 6. WORLD HEALTH ORGANIZATION, Preventing Chronic Diseases: A Vital Investment. WHO Global Report (WHO, Geneva, 2005). - 7. MATHERS C, STEVENS G, MASCARENHAS M. Global health risks: mortality and burden of disease attributable to selected major risks (WHO Geneva, 2009). - 8. LAWES CM, VANDER HOORN S, RODGERS A, Lancet, 371 (2008) 1513. - 9. ERCEG M, HRABAK-ŽERJAVIĆ V, IVIČEVIĆ UHERNIK A, Acta Med Croatica, 61 (2007) 293. - 10. FIŠTER K, KOLČIĆ I, MUSIĆ MILANOVIĆ S, KERN J, Coll Antropol, 33 Suppl 1 (2009) 25. - 11. HUBERT HB, FEINLEIB M, MCNAMARA PM, CASTELLI WP, Circulation, 67 (1983) 968. - 12 JOUSILAHTI P, TUOMILEHTO J, VARTIAINEN E, PEKKANEN J, PUSKA P, Circulation, 93 (1996) 1372. - 13. KANNEL WB, GORDON T, CASTELLI WP, Am J Clin Nutr, 32 (1979) 1238. - 14. RENEHAN AG, TYSON M, EGGER M, HELLER RF, ZWAHLEN M, Lancet, 371 (2008) 569. - 15. LA VECCHIA C, PARAZZINI F, NEGRI E, FASOLI M, GENTILE A, FRANCESCHI S, Eur J Cancer, 27 (1991) 487. - 16. GARFINKEL L, Ann Intern Med, 203 (1985)1034. - 17. LUBIN F, RUDER AM, WAX Y, MODAN B, Am J Epidemiol, 22 (1985) 579. - 18. CHYOU PH, NOMURA AM, STEMMERMANN GN, Int J Cancer, 57 (1994) 313. — 19. WITTELS EH, THOMPSON S, Otolaryngol Clin North Am, 23 (1990) 751 - 20. IVIČEVIĆ UHERNIK A, VULETIĆ S, KERN J, DEČKOVIĆVUKRES V, MIHEL S, ERCEG M, PRISTAŠ I, Coll Antropol, 36 (Suppl 1) (2012) 3. - 21. FORD ES, Circulation, 123 (2011) 1737. — 22. GU Q, DILLON CF, BURT VL, GILLUM RF, Am J Hypertens, 23 (2010) 38. 23. KANNEL WB, JAMA, 275 (1996) 1571. - 24. MACMAHON S, PETO R, CUTLER J, COLLINS R, SORLIE P, NEATON J, ABBOTT R, GODWIN J, DYER A, STAMLER J, Lancet, 335 (1990) 765. - 25. ASSMANN G, SCHULTE H. Am Heart J, 116 (1988) 1713. — 26. WALKER WG, NEATON JD, CUTLER JA, NEUWIRTH R, COHEN JD, JAMA, 268 (1992) 3085. - 27. VASAN RS, LARSON MG, LEIP EP, EVANS JC, O’DONNELL CJ, KANNEL WB, LEVY D, N Engl J Med, 345 (2001)1291. - 28. CUSPIDI C, AMBROSIONI E, MANCIA G, PESSINA AC, TRIMARCO B, ZANCHETTI A; APROS INVESTIGATORS, J Hypertens, 20 (2002)1307. - 29. ISOMAA B, ALMGREN P, TUOMI T, FORSEN B, LAHTI K, NISSÉN M, TASKINEN MR, GROOP L, Diabetes Care, 24 (2001) 683. — 30. BULPITT CJ, FLETCHER AM, J Hypertens Suppl, 10 (1992) model of intervention « (108-1080135-0264) supported by Ministry of Science, Education and Sport of the Republic of Croatia.

S45. - 31. PROSPECTIVE STUDIES COLLABORATION, WHITLOCK G, LEWINGTON S, SHERLIKER P, CLARKE R, EMBERSON J, HALSEY J, QIZILBASH N, COLLINS R, PETO R, Lancet, 373 (2009) 1083. - 32. BERRINGTON DE GONZALEZ A, HARTGE P, CERHAN JR, FLINT AJ, HANNAN L, MACINNIS RJ, MOORE SC, TOBIAS GS ANTON-CULVER H, FREEMAN LB, BEESON WL, CLIPP SL, ENGLISH DR, FOLSOM AR, FREEDMAN DM, GILES G, HAKANSSON N, HENDERSON KD, HOFFMAN-BOLTON J, HOPPIN JA, KOENIG KL, LEE IM, LINET MS, PARK Y, POCOBELLI G, SCHATZKIN A, SESSO HD, WEIDERPASS E, WILLCOX BJ, WOLK A, ZELENIUCH-JACQUOTTE A, WILLETT WC, THUN MJ, N Engl J Med, 363 (2010) 2211. — 33. ADAMS KF, SCHATZKIN A, HARRIS TB, KIPNIS V, MOUW T, BALLARD-BARBASH R, HOLLENBECK A, LEITZMANN MF, N Engl $J$ Med, 355 (2006) 763. — 34. MCGEE DL, Ann Epidemiol, 15 (2005) 87. 35. FONTAINE KR, REDDEN DT, WANG C, WESTFALL AO, ALLISON DB, JAMA. 289 (2003) 187. — 36. LENZ M, RICHTER T, MÜHLHAUSER I, Dtsch Arztebl Int, 106 (2009) 641. - 37. FLEGAL KM, GRAUBARD BI, WILLIAMSON DF, GAIL MH, JAMA, 293 (2005) 1861. — 38. ORPANA HM, BERTHELOT JM, KAPLAN MS, FEENY DH, MCFARLAND B, ROSS NA, Obesity, 18 (2010) 214. - 39. MCGEE DL, Ann Epidemiol, 15 (2005) 87. - 40. DYER AR, STAMLER J, GARSIDE DB, GREENLAND P, Ann Epidemiol, 14 (2004) 101. - 41. LAWLOR DA, HART CL, HOLE DJ, DAVEY SMITH G, Obesity (Silver Spring) 14 (2006) 2294. 42. FLEGAL KM, GRAUBARD BI, WILLIAMSON DF, GAIL MH, JAMA 298 (2007) 2028. - 43. CURTIS JP, SELTER JG, WANG Y, RATHORE SS, JOVIN IS, JADBABAIE F, KOSIBOROD M, PORTNAY EL, SOKOL SI, BADER F, KRUMHOLZ HM, Arch Intern Med, 165 (2005) 55. - 44 MANSON JE, STAMPFER MJ, HENNEKENS CH, WILLETT WC, JAMA, 257 (1987) 353. - 45. JACOBS DR JR, GOTTENBORG S, Am J Public Health, 71 (1981) 391. - 46. WANNAMETHEE SG, SHAPER AG, WALKER M, Int J Epidemiol, 30 (2001) 777. — 47. CALLE EE, THUN MJ, PETRELLI JM, RODRIGUEZ C, HEATH CW JR, N Engl J Med, 341 (1999)1097. - 48. KRUMHOLZ HM, Arch Intern Med, 165 (2005) 55. 49. TAYBACK M, KUMINYIKA 5, CHEE E, Arch Intern Med, 150 (1990) 1065. - 50. STEVENS J, CAI J, PAMUK ER, WILLIAMSON DF, THUN MJ, WOOD JL, N Engl J Med, 338 (1998) 1. - 51. DIEHR P, O'MEARA ES, FITZPATRICK A, NEWMAN AB, KULLER L, BURKE G, J Am Geriatr Soc, 56 (2008) 76. - 52. DOLAN CM, KRAEMER H, BROWNER W, ENSRUD K, KELSEY JL, Am J Public Health, 97 (2007) 913. — 53. DIEHR P, BILD DE, HARRIS TB, DUXBURY A, SISCOVICK D, ROSSI M, Am J Public Health, 88 (1998) 623. - 54. OREOPOULOS A, KALANTAR-ZADEH K, SHARMA AM, FONAROW GC, Clin Geriatr Med, 25 (2009) 643. - 55. BORKAN GA, HULTS DE, GERZOF SG, ROBBINS AH, SILBERT CK, J Gerontol, 38 (1983) 673.

\section{S. Mihel}

Croatian National Institute of Public Health, Rockefellerova 7, 10000 Zagreb, Croatia e-mail:sandra.mihel@hzjz.hr

\section{POVEZANOST POVEĆANOG INDEKSA TJELESNE MASE I HIPERTENZIJE S MORTALITETOM U HRVATSKOJ KOHORTNOJ STUDIJI KARDIOVASKULARNOG ZDRAVLJA 2003/08}

\section{S A ŽZ E T A K}

Cilj ovog rada bio je istražiti povezanost povećanog indeksa tjelesne mase (ITM) i hipertenzije s općim mortalitetom u kohorti ispitanika Hrvatske kohortne studije kardiovaskularnog zdravlja 2003/08. Rizik od smrti prema kategorijama 
indeksa tjelesne mase i krvnog tlaka, u razdoblju 2003-08. godine, izračunat je za 7,490 ispitanika, od kojih je u 2008. godini bilo 6,682 živih i 808 mrtvih. Kod muškaraca u dobi od 65 i više godina, povećan ITM bio je povezan s manjim rizikom od smrti u skladu s paradoksom debljine zabilježenim u nekim prethodnim studijama koje su pokazale sa stariji muškarci višim ITM imaju manji rizik od smrti. Kod žena u dobi 50-64 godine, prisutnost hipertenzije bila je povezana s povećanim rizikom od smrti u usporedbi s ispitanicama s normalnim krvnim tlakom. Usprkos paradoksu debljine koji traži daljnja istraživanja, potrebno je poticati aktivnosti u primarnoj i sekundarnoj prevenciji prekomjerne tjelesne težine i hipertenzije kao sredstvima za sprječavanje prerane smrtnosti u hrvatskom stanovništvu. 